\title{
assessment of healthcare wastes management at egyptian hospital: case study at qotour general hospital
}

\author{
Hasnaa Basiouny Khedre ${ }^{1}$,Ali H.H.Saleh ${ }^{2}$,Walid SobhyQ.Abdo ${ }^{3}$ \\ ${ }^{1-}$ Research Institute Environmental Studies - El-Sadat City University \\ ${ }^{2-}$ Environmental Studies and Research Institute, El-Sadat City University \\ 3- ,faculty of veterinary edicine Kafr EL-Sheikh University.
}

\section{ABSTRACT}

Waste management is a collection, transportation, and disposal of garbage, sewage, and other waste products. Waste management is the process of treating solid wastes and offers a variety of solutions for recycling items that don't belong to trash. The aim of this study was to review and assess the current status of medical waste management practices at Qutour General Hospital. A descriptive cross-sectional and observational design was used. The study was conducted at Egyptian Hospitals and Case Study of Qutour General Hospital. A random sample of sixty participants from the medical and nursing staff and workers by simple randomization. One tool was used for data collection: A structured questionnaire schedule: consists of two parts, social characteristics of the study sample and a questionnaire to collect information on the management of medical waste. The results show there was proper knowledge among all health care workers related to waste segregation regarding general, infectious and sharps waste. workers have knowledge related to color-coded bags and medical waste storage and transport despite not reading the written policies of waste management. The study concluded a gap between current knowledge of hospital waste management among health-care workers and that demanded by hospital waste management implementation policies. All the storage waste rooms were inappropriate, the studied hospitals had records for delivered and received wastes but incomplete. The study recommended establishing a medical waste system to implement the existing legislation, establish a waste management team, development of in-service training programs for health care workers and written policies or clear procedures of waste management should be available at ambulatory clinics.

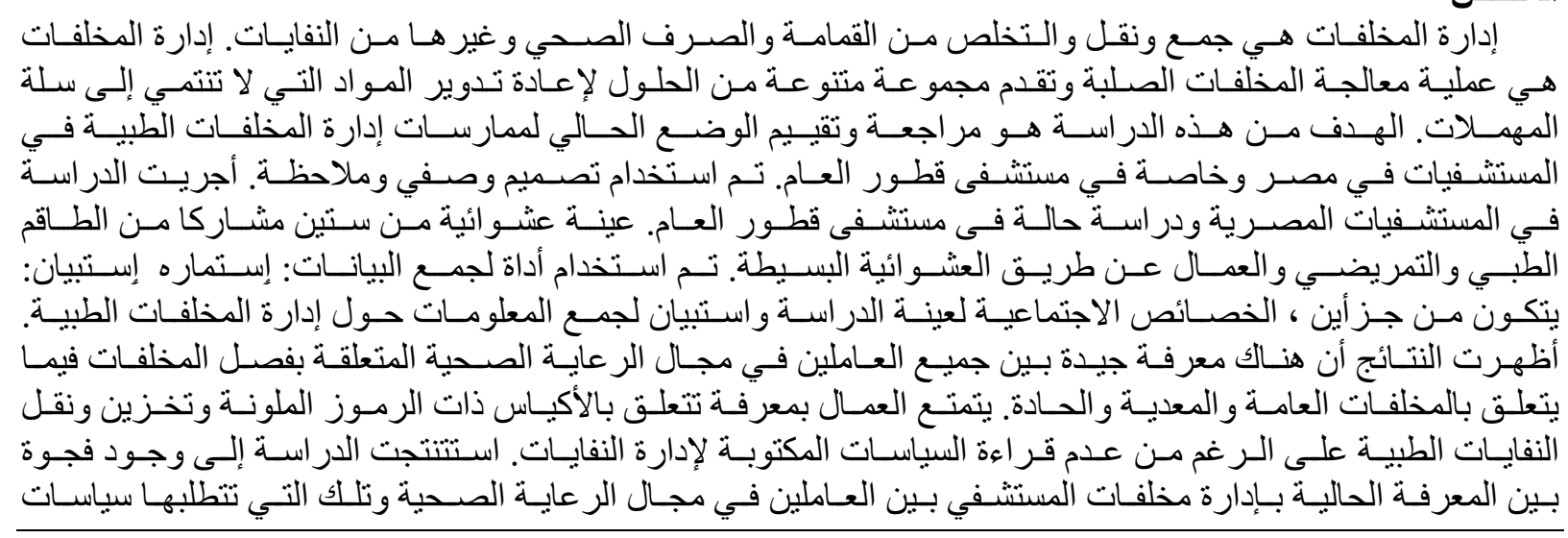




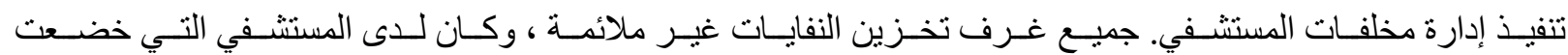

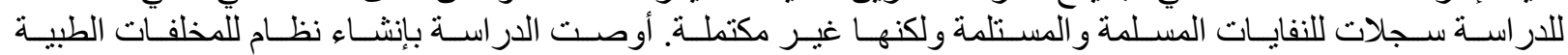

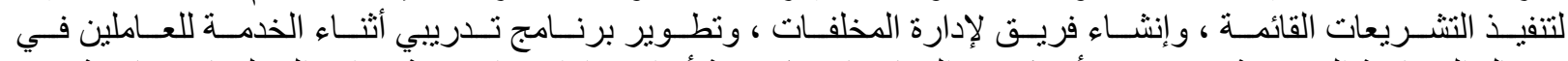

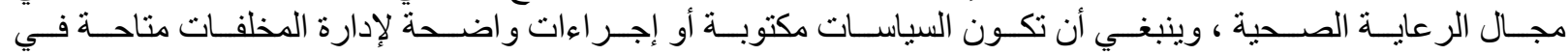
العيادات المتنقلة.

\section{INTRODUCTION}

Medical wastes could be defined as waste generated during the testing, treatment, diagnosis, research or production of biological products for humans or animals. Medical wastes include many items such as syringes, bodily fluids, body parts, live vaccines, laboratory samples, and waste, sharp needles, cultures, and lancets (Pasupathi et al., 2011). Healthcare waste management includes all activities involved in waste generation, transportation, segregation, storage, treatment and final disposal of all types of waste generated in the healthcare facilities, stages of which require special attention (Manyele and Lyasenga, 2010). In fact, $75-90 \%$ of the health care wastes are non-hazardous and as harmless as any other municipal waste. The remaining $10-25 \%$ is dangerous and can be injurious to humans or animals and deleterious to the environment. It is important to know that if both these types are mixed together then the whole waste becomes harmful (Pasupathi et al., 2011).

The Egyptian Environmental Protection Law adopted the WHO classification of healthcare settings waste items into "six categories": Sharps (needles, glass vials or scalpel blades); Pathological (anatomical body parts, microbiology cultures, and blood samples); Infectious wastes (items contaminated with body fluids and discharges such as dressing, catheters, and intravenous lines); Chemical and radioactive wastes (mercury-containing instruments and PVC plastics); Pressurized containers and Pharmaceutical waste (Egyptian Prime Minister, 2019).

All individuals, who are exposed to hazardous HCWs are potentially at risk of being injured or infected. They include medical staff: doctors, pharmacists, laboratory technologists, nurses, paramedics, sanitary staff and hospital maintenance personnel. In and outpatients: receiving treatment in HCFs as well as their visitors. Workers in support services: linked to HCFs such as laundries, waste handling, and transportation Services. Workers in waste disposal facilities: including scavengers. The general public: mostly the children playing with the items they can find in the waste outside the HCFs when it is directly accessible to them. (Gurung, et al, 2010).

Segregation is a very important step in the waste management process. It is a process of separation of waste into designated categories, this enables those who handle the containers outside the hospital wards to identify and treat them appropriately. Also, it decreases medical waste and this also reduces the health impacts on the general public and the budget required for health care waste disposal (El-Sayed et al., 2012). 
Treatment processes for medical wastes include autoclaving, microwaving, chemical disinfection, irradiation, plasma system and incineration (Labib et al., 2005). The amount of waste produced in a hospital depends on the level of national income and the type of facility concerned. It is reported that one university hospital in a high-income country can produce up to $10 \mathrm{~kg}$ of waste per bed per day, all categories combined (ICRC, 2011).

Inadequate collection, storage, disposal and treatment of these wastes can lead to serious environmental damage of various kinds. Some of the health problems related to improper collection, treatment, and disposal of healthcare waste include cholera, skin disease, typhoid fever, malaria, and other diseases. So that, the disposal of items used at health institutions must be handled with utmost care so as to ensure that health care workers, patients and members of the community at large are protected from the dangers of secondary transmission of diseases and cause of injuries.

\section{Aim of the study}

The study was conducted to review and assess the current status of medical waste management practices at hospitals in Egypt, especially in Qutour general hospital.

\section{Materials and Methods}

This is a descriptive cross-sectional and observational study of a regional hospital. The study was conducted at; Egyptian Hospitals and Case Study of Qutour General Hospital.

Sample: Random sample of sixty participants from the medical and nursing staff and workers by simple randomization from the previous mention setting and assigned according to the power analysis equation. The sample size was based on the following parameters confidence level error level 5\% type I error 0.05 and power of test $90 \%$.

\section{Tools of data collection:}

The tool was developed by the researcher based on previous references related to the management of medical waste and used to collect the data required data as follows:

A structured questionnaire schedule: It was used to assess the participants from the medical, nursing staff and workers current status of medical waste management practices at hospitals and consists of two parts:

Part I: Social characteristics of the study sample such as age, sex, and education.

Part II: Includes a questionnaire to collect information on the management of medical waste (after taking the necessary administrative approvals for this purpose). 


\section{Method:}

Official permission to conduct the study was obtained from the director of Qutour General Hospital to obtain their approval and cooperation during the study. The nature of the study would not cause any harm or pain to the entire sample. Oral consents were obtained from the participants from the medical, nursing staff and workers to participate in the study after explaining the aim of the study and their right to withdraw from the study at any time without providing a reason and without any potential. The medical, nursing staff and workers were informed about the confidentiality of their information and it was used only for the purpose of the study.

The tool was presented to a jury of five experts in the field of waste management to check content validity clarity, relevance, comprehensiveness, understanding, applicability, and ease for implementation. The content validity index was $98.5 \%$. To assess reliability, the study tools were tested and the value of Cronbach's alpha coefficient was 0.882. A pilot study was carried out before starting the data collection. It was done on a sample of $10 \%$ of the study sample to test clarity, visibility, and applicability of the study tools. This pilot was excluded from the study.

\section{Implementation of the study: The study was conducted through four phases:}

Assessment phase: Initial interview with the study sample was done at Qutour General Hospital by using tools

Planning phases: Interview was developed by the researcher; priorities goal and expected outcomes criteria were formulated.

Implementation phase: Before the beginning of the interview, participants from the medical, nursing staff and workers were divided into 12 groups and each group included 5 persons. Duration for interviews ranged from 20- 30 minutes. Data were collected over a period of 3 months starting from March 2018 till the end of May 2018.

Evaluation phase: The interview was evaluated immediately after the completion by using a constructed tool.

\section{Statistical analysis:}

The data collected were organized, tabulated and statistically analyzed using SPSS software (Statistical Package for the Social Sciences, version 23, SPSS Inc. Chicago, IL, USA). For quantitative data, the range, mean and standard deviation were calculated. For qualitative data, a comparison between two groups and more was done using Chi-square test $(\chi 2)$. For comparison between the means of two groups of nonparametric data of independent samples, $Z$ value of Mann-Whitney $U$ test was used. Significance was adopted at $\mathrm{p}<0.05$ for the interpretation of the results of tests of significance (Dawson B D et al., 2001).

\section{Result}

I- Social characteristics; Table (1): As regards the age, it was found that the mean age was $31.00 \pm 4.84,26.15 \pm 4.22$ and $31.45 \pm 6.22$ for the doctors, nurses, and workers respectively. Three-quarters of the doctors $(75.0 \%), 65.0 \%$ of workers 
were male while, almost of nurses $(95.0 \%)$ were female. As regards marital status, most of the doctors (80.0\%), Three quarter of the nurses (75.0) and $60.0 \%$ of workers were married. Concerning the educational level, it was found that half of the doctors $(50.0 \%)$ had a bachelor's and master's degrees, $60 \%$ of nurses and $70 \%$ of workers had diplom. Also, it shows $40.0 \%$ of the doctors, $45.0 \%$ of the nurses and less than two thirds $(60.0 \%)$ of workers had more than five years working in the hospital. Regarding training to deal with medical waste by type, there was found almost the doctors $(90.0 \%)$, half of the nurses $(50.0 \%)$ and three-quarters of the workers $(75.0 \%)$ no received any training.

II- Information regarding medical waste segregation and color coding for waste segregation; Figure (1): It was indicated that almost of doctors (90\%), all of the nurses $(100.0 \%)$ and $65.0 \%$ of workers indicated that medical waste separated from regular waste. And also, all of the study samples answered there was color coding for waste separated in the hospital.

III- Information related to safety measures of health care members; Table (2): It was observed that $90.0 \%$ of the doctor and all of the nurses and workers $(100.0 \%)$ answered yes always for workers use gloves while handling medical waste. Regarding using the workers the same gloves more than once, $40.0 \%$ of the doctors and nurses answered yes always and sometimes respectively, while half of the workers $(50.0 \%)$ answered sometimes. Regarding the place of discarded gloves, half of the doctors answered with regular waste, while all of the nurses and workers $(100.0 \%)$ answered with medical waste.

On the other hand, $30.0 \%$ of the doctors answered yes always and rarely, and more than half $(55.0 \%)$ of nurses and all of the workers $(100.0 \%)$ answered yes always for wearing the worker's protective clothing. As regard protective clothing so that they do not allow needles to penetrate, almost of the doctors $(90.0 \%)$ don't know while all of nurses and workers (100.0\%) answered non-protective. Moreover, the table showed that $60.0 \%$ of the doctors, most of the nurses $(90.0 \%)$ and three-quarters of the workers $(75.0 \%)$ reported they not acupuncture after use at work.

IV- Information regarding a specific mark showing the storage area of medical waste, storage area sufficient inside hospital and the storage area protected well; Figure (2): About a specific mark showing the storage area of medical waste, half of the doctors $(50.0 \%)$, three-quarters of nurses $(75.0 \%)$ and all of the workers $(100.0 \%)$ were answered yes. As regards to the storage area sufficient inside the hospital, all of the doctors (100.0\%) answered don't know while $45.0 \%$ and $65.0 \%$ of the nurses and the workers respectively were answered yes. All of the doctors $(100.0 \%)$ and half of the nurses $(50.0 \%)$ answered don't know the storage area protected well while threequarters of the workers (75.0\%) answered yes always. 
V- Information regarding a clean the means of transporting waste, the surface of the transportation smooth and waste transferring means permeable to liquids; Figure (3): Regarding a clean the means of transporting waste, the half of the doctors answered don't know while $40.0 \%$ of nurses and all of the workers $(100.0 \%)$ answered yes. Also, three-quarters of the doctors $(75.0 \%)$ don't know the surface of the transportation smooth while, all of the nurses and the workers $(100.0 \%)$ were answered yes. Regarding waste transferring mean permeable to liquids, all the participants answered no.

VI- Information regarding medical waste sharp box; Figure (4): It was clear that there was no medical waste burning inside the hospital as $60.0 \%$ of the doctors, most of the nurses $(90.0 \%)$ and all of the worker $(100.0 \%)$ indicated that and the others said they don't know. all of the respondents $(100.0 \%)$ said that containers used to discard needles were not vulnerable to punching. On the other hand, all of them $(100.0 \%)$ said that these containers were not difficult to open. Regarding specific marks indicating waste type inside the hospital, $55.0 \%$ of the doctors, all most of the nurses $(90.0 \%)$ and all of the workers $(100.0 \%)$ answered yes.

Table (1): Percent distribution of social characteristics of the study sample. $(n=60)$

\begin{tabular}{|c|c|c|c|c|c|c|c|c|}
\hline \multirow{3}{*}{$\begin{array}{l}\text { Social characteristics of } \\
\text { the study sample }\end{array}$} & \multicolumn{8}{|c|}{ The study sample $(n=60)$. } \\
\hline & \multicolumn{2}{|c|}{$\begin{array}{l}\text { Doctors } \\
(\mathbf{n}=\mathbf{2 0})\end{array}$} & \multicolumn{2}{|c|}{ Nurses $(n=20)$} & \multicolumn{2}{|c|}{$\begin{array}{l}\text { Workers } \\
(\mathrm{n}=\mathbf{2 0})\end{array}$} & \multirow[t]{2}{*}{$\begin{array}{l}\text { Test } \\
\text { of Sig. }\end{array}$} & \multirow[t]{2}{*}{$\mathbf{P}$} \\
\hline & No & $\%$ & No & $\%$ & No & $\%$ & & \\
\hline $\begin{array}{l}\text { Age in years: } \\
\text { Range } \\
\text { Means }\end{array}$ & \multicolumn{2}{|c|}{$\begin{array}{l}25-40 \\
31.00 \pm 4.84\end{array}$} & \multicolumn{2}{|c|}{$\begin{array}{l}20-36 \\
26.15 \pm 4.22\end{array}$} & \multicolumn{2}{|c|}{$\begin{array}{l}22-42 \\
31.45 \pm 6.22\end{array}$} & $\begin{array}{l}\begin{array}{l}\text { MWU } \\
=\end{array} \\
0.135\end{array}$ & $\begin{array}{l}0.89 \\
2 \\
\end{array}$ \\
\hline $\begin{array}{l}\text { Sex: } \\
\text { Males } \\
\text { Females }\end{array}$ & $\begin{array}{l}15 \\
5\end{array}$ & $\begin{array}{l}75.0 \\
25.0\end{array}$ & $\begin{array}{l}1 \\
19 \\
\end{array}$ & $\begin{array}{l}5.0 \\
95.0\end{array}$ & \begin{tabular}{|l}
7 \\
13 \\
\end{tabular} & $\begin{array}{l}35.0 \\
65.0\end{array}$ & $\begin{array}{l}\chi 2= \\
17.253\end{array}$ & $\begin{array}{l}0.00 \\
0^{*}\end{array}$ \\
\hline $\begin{array}{l}\text { Marital status } \\
\text { Married } \\
\text { Single } \\
\text { Divorced } \\
\text { Widowed } \\
\end{array}$ & $\begin{array}{l}16 \\
4 \\
0 \\
0 \\
\end{array}$ & $\begin{array}{l}80.0 \\
20.0 \\
0.0 \\
0.0 \\
\end{array}$ & $\begin{array}{l}15 \\
3 \\
1 \\
0 \\
\end{array}$ & $\begin{array}{l}75.0 \\
15.0 \\
5.0 \\
0.0 \\
\end{array}$ & $\begin{array}{l}12 \\
3 \\
2 \\
3 \\
\end{array}$ & $\begin{array}{l}60.0 \\
15.0 \\
10.0 \\
15.0 \\
\end{array}$ & $\begin{array}{l}\chi 2= \\
41.396\end{array}$ & $\begin{array}{l}0.00 \\
0 *\end{array}$ \\
\hline $\begin{array}{l}\text { Educational level } \\
\text { Read and write } \\
\text { Preparatory } \\
\text { Diploma } \\
\text { Bachelor } \\
\text { Master } \\
\end{array}$ & $\begin{array}{l}0 \\
0 \\
0 \\
10 \\
10 \\
\end{array}$ & $\begin{array}{l}0.0 \\
0.0 \\
0.0 \\
50.0 \\
50.0 \\
\end{array}$ & \begin{tabular}{|l}
0 \\
0 \\
12 \\
7 \\
1 \\
\end{tabular} & $\begin{array}{l}0.0 \\
0.0 \\
60.0 \\
35.0 \\
5.0 \\
\end{array}$ & \begin{tabular}{|l}
3 \\
3 \\
14 \\
0 \\
0 \\
\end{tabular} & $\begin{array}{l}15.0 \\
15.0 \\
70.0 \\
0.0 \\
0.0 \\
\end{array}$ & $\begin{array}{l}\chi 2= \\
51.070\end{array}$ & $\begin{array}{l}0.00 \\
0^{*}\end{array}$ \\
\hline $\begin{array}{l}\text { Working period (years) } \\
\text { Less than five years } \\
\text { Five years } \\
\text { More than five years }\end{array}$ & $\begin{array}{l}7 \\
5 \\
8\end{array}$ & $\begin{array}{l}35.0 \\
25.0 \\
40.0\end{array}$ & $\begin{array}{l}5 \\
6 \\
9\end{array}$ & $\begin{array}{l}25.0 \\
30.0 \\
45.0\end{array}$ & $\begin{array}{l}3 \\
5 \\
12\end{array}$ & $\begin{array}{l}15.0 \\
25.0 \\
60.0\end{array}$ & MWU & 0.49 \\
\hline
\end{tabular}




\begin{tabular}{|c|c|c|c|c|c|c|c|c|}
\hline \multirow[t]{2}{*}{$\begin{array}{l}\text { Range } \\
\text { Means }\end{array}$} & & & & & & & $\begin{array}{l}= \\
0.711\end{array}$ & 5 \\
\hline & \multicolumn{2}{|c|}{$\begin{array}{l}3-10 \\
5.92 \pm 2.37\end{array}$} & \multicolumn{2}{|c|}{$\begin{array}{l}4-12 \\
6.20 \pm 2.41\end{array}$} & \multicolumn{2}{|c|}{$\begin{array}{l}1-11 \\
6.15 \pm 2.30\end{array}$} & & \\
\hline $\begin{array}{c}\text { Department } \\
\text { Surgery } \\
\text { Pediatric } \\
\text { Laboratory } \\
\text { Operation } \\
\text { Medical } \\
\end{array}$ & $\begin{array}{l}4 \\
3 \\
2 \\
7 \\
4 \\
\end{array}$ & $\begin{array}{l}20.0 \\
15.0 \\
10.0 \\
35.0 \\
20.0 \\
\end{array}$ & $\begin{array}{l}2 \\
5 \\
1 \\
9 \\
3 \\
\end{array}$ & $\begin{array}{l}10.0 \\
25.0 \\
5.0 \\
45.0 \\
15.0 \\
\end{array}$ & $\begin{array}{l}4 \\
2 \\
2 \\
10 \\
2 \\
\end{array}$ & $\begin{array}{l}20.0 \\
10.0 \\
10.0 \\
50.0 \\
10.0 \\
\end{array}$ & $\begin{array}{l}\chi 2= \\
3.805\end{array}$ & $\begin{array}{l}0.87 \\
4\end{array}$ \\
\hline $\begin{array}{l}\text { Training to deal with } \\
\text { medical waste by type } \\
\text { Yes } \\
\text { No }\end{array}$ & $\begin{array}{l}2 \\
18\end{array}$ & $\begin{array}{l}10.0 \\
90.0\end{array}$ & $\begin{array}{l}10 \\
10\end{array}$ & $\begin{array}{l}50.0 \\
50.0\end{array}$ & $\begin{array}{l}5 \\
15\end{array}$ & $\begin{array}{l}25.0 \\
75.0\end{array}$ & $\begin{array}{l}\chi^{2}= \\
8.044\end{array}$ & $\begin{array}{l}0.01 \\
8^{*}\end{array}$ \\
\hline
\end{tabular}

* Statistically significant difference at $(\mathbf{P}<\mathbf{0 . 0 5}) . \quad$ MWU $\rightarrow$ Mann-Whitney U test. $\chi 2 \rightarrow$ Chi-square test.

Figure (1): Percent distribution of the study sample information regarding medical waste segregation and color coding for waste segregation $(n=60)$

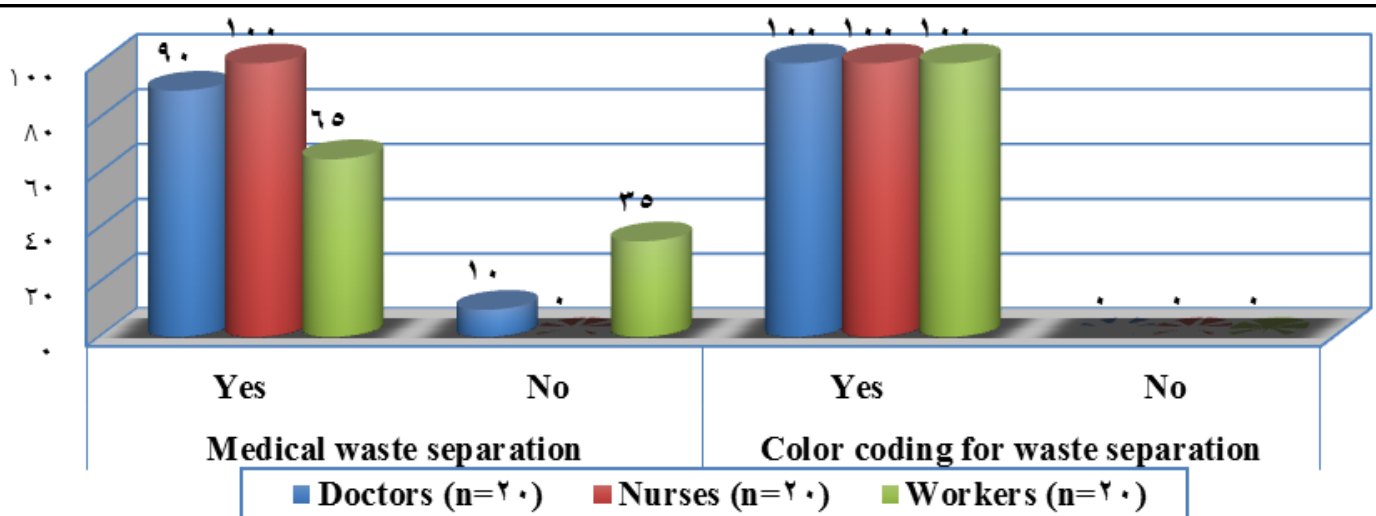

Table (2): Percent distribution of the study sample information related to safety measures of health care members $(n=60)$

\begin{tabular}{|c|c|c|c|c|c|c|c|c|}
\hline \multirow{3}{*}{ Safety measures of cleaners } & \multicolumn{8}{|c|}{ The study sample $(n=60)$. } \\
\hline & \multicolumn{2}{|c|}{\begin{tabular}{|l} 
Doctors \\
$(\mathrm{n}=\mathbf{2 0})$
\end{tabular}} & \multicolumn{2}{|c|}{ Nurses $(n=20)$} & \multicolumn{2}{|c|}{$\begin{array}{l}\text { Workers } \\
(\mathrm{n}=20)\end{array}$} & \multirow{2}{*}{$\begin{array}{l}\text { Test } \\
\text { of } \\
\text { Sig. }\end{array}$} & \multirow[t]{2}{*}{$\mathbf{P}$} \\
\hline & No & $\%$ & No & $\%$ & No & $\%$ & & \\
\hline $\begin{array}{l}\text { Do workers use gloves while } \\
\text { handling medical waste? } \\
\text { Yes always } \\
\text { Don't know }\end{array}$ & $\begin{array}{l}18 \\
2\end{array}$ & $\begin{array}{l}90.0 \\
10.0\end{array}$ & $\begin{array}{l}20 \\
0\end{array}$ & $\begin{array}{l}100.0 \\
0.0\end{array}$ & $\begin{array}{l}20 \\
0\end{array}$ & $\begin{array}{l}100.0 \\
0.0\end{array}$ & $\begin{array}{l}\chi 2= \\
4.136\end{array}$ & $\begin{array}{l}0.12 \\
6\end{array}$ \\
\hline $\begin{array}{l}\text { the workers use the same } \\
\text { gloves more than once } \\
\text { Yes always } \\
\text { Sometimes } \\
\text { Rarely } \\
\text { No } \\
\text { Don't know } \\
\end{array}$ & \begin{tabular}{|l}
8 \\
5 \\
4 \\
0 \\
3 \\
\end{tabular} & $\begin{array}{l}40.0 \\
25.0 \\
20.0 \\
0.0 \\
15.0 \\
\end{array}$ & $\begin{array}{l}7 \\
8 \\
3 \\
2 \\
0 \\
\end{array}$ & $\begin{array}{l}35.0 \\
40.0 \\
15.0 \\
10.0 \\
0.0 \\
\end{array}$ & \begin{tabular}{|l}
5 \\
10 \\
3 \\
2 \\
0 \\
\end{tabular} & \begin{tabular}{|l}
25.0 \\
50.0 \\
15.0 \\
10.0 \\
0.0 \\
\end{tabular} & $\begin{array}{l}\chi 2= \\
10.55 \\
2\end{array}$ & $\begin{array}{l}0.22 \\
8\end{array}$ \\
\hline
\end{tabular}




\begin{tabular}{|c|c|c|c|c|c|c|c|c|}
\hline $\begin{array}{l}\text { Where do the workers discard } \\
\text { the gloves? } \\
\text { With medical waste } \\
\text { With medical and ordinary } \\
\text { waste } \\
\text { With regular waste }\end{array}$ & $\begin{array}{l}5 \\
5 \\
10\end{array}$ & $\begin{array}{l}25.0 \\
25.0 \\
50.0\end{array}$ & $\begin{array}{l}20 \\
0 \\
0\end{array}$ & $\begin{array}{l}100.0 \\
0.0 \\
0.0\end{array}$ & $\begin{array}{l}20 \\
0 \\
0\end{array}$ & $\begin{array}{l}100.0 \\
0.0 \\
0.0\end{array}$ & $\begin{array}{l}\chi^{2}= \\
40.00 \\
0\end{array}$ & $\begin{array}{l}0.00 \\
0^{*}\end{array}$ \\
\hline $\begin{array}{lll}\text { workers wear special clothes } \\
\text { at work } & & \\
\text { Yes always } & & \\
\text { Sometimes } & & \\
\text { Rarely } & & \\
\text { No } & & \\
\text { Don't know } & & \\
\end{array}$ & $\begin{array}{l}6 \\
4 \\
6 \\
2 \\
2\end{array}$ & $\begin{array}{l}30.0 \\
20.0 \\
30.0 \\
10.0 \\
10.0\end{array}$ & $\begin{array}{l}11 \\
8 \\
1 \\
0 \\
0\end{array}$ & $\begin{array}{l}55.0 \\
40.0 \\
5.0 \\
0.0 \\
0.0\end{array}$ & $\begin{array}{l}20 \\
0 \\
0 \\
0 \\
0\end{array}$ & $\begin{array}{l}100.0 \\
0.0 \\
0.0 \\
0.0 \\
0.0\end{array}$ & $\begin{array}{l}\chi 2= \\
33.01 \\
9\end{array}$ & $\begin{array}{l}0.00 \\
0^{*}\end{array}$ \\
\hline $\begin{array}{l}\text { Are these protective clothing } \\
\text { so that they do not allow } \\
\text { needles to penetrate? } \\
\text { Non-protective } \\
\text { I do not know }\end{array}$ & $\begin{array}{l}2 \\
18\end{array}$ & $\begin{array}{l}10.0 \\
90.0\end{array}$ & $\begin{array}{l}20 \\
0\end{array}$ & $\begin{array}{l}100.0 \\
0.0\end{array}$ & $\begin{array}{l}20 \\
0\end{array}$ & $\begin{array}{l}100.0 \\
0.0\end{array}$ & $\begin{array}{l}\chi 2= \\
51.42 \\
9\end{array}$ & $\begin{array}{l}0.00 \\
0 *\end{array}$ \\
\hline $\begin{array}{l}\text { Have you been acupuncture } \\
\text { after use at work? } \\
\text { Yes } \\
\text { No } \\
\end{array}$ & $\begin{array}{l}8 \\
12 \\
\end{array}$ & $\begin{array}{l}40.0 \\
60.0 \\
\end{array}$ & $\begin{array}{l}2 \\
18 \\
\end{array}$ & $\begin{array}{l}10.0 \\
90.0 \\
\end{array}$ & $\begin{array}{l}5 \\
15 \\
\end{array}$ & $\begin{array}{l}25.0 \\
75.0 \\
\end{array}$ & $\begin{array}{l}\chi 2= \\
4.800\end{array}$ & $\begin{array}{l}0.09 \\
1\end{array}$ \\
\hline
\end{tabular}

* Statistically significant difference at $(\mathbf{P}<0.05)$

Figure (2): Percent distribution of the study sample information regarding a specific mark showing the storage area of medical waste, storage area sufficient inside the hospital and the storage area protected well. $(n=60)$.

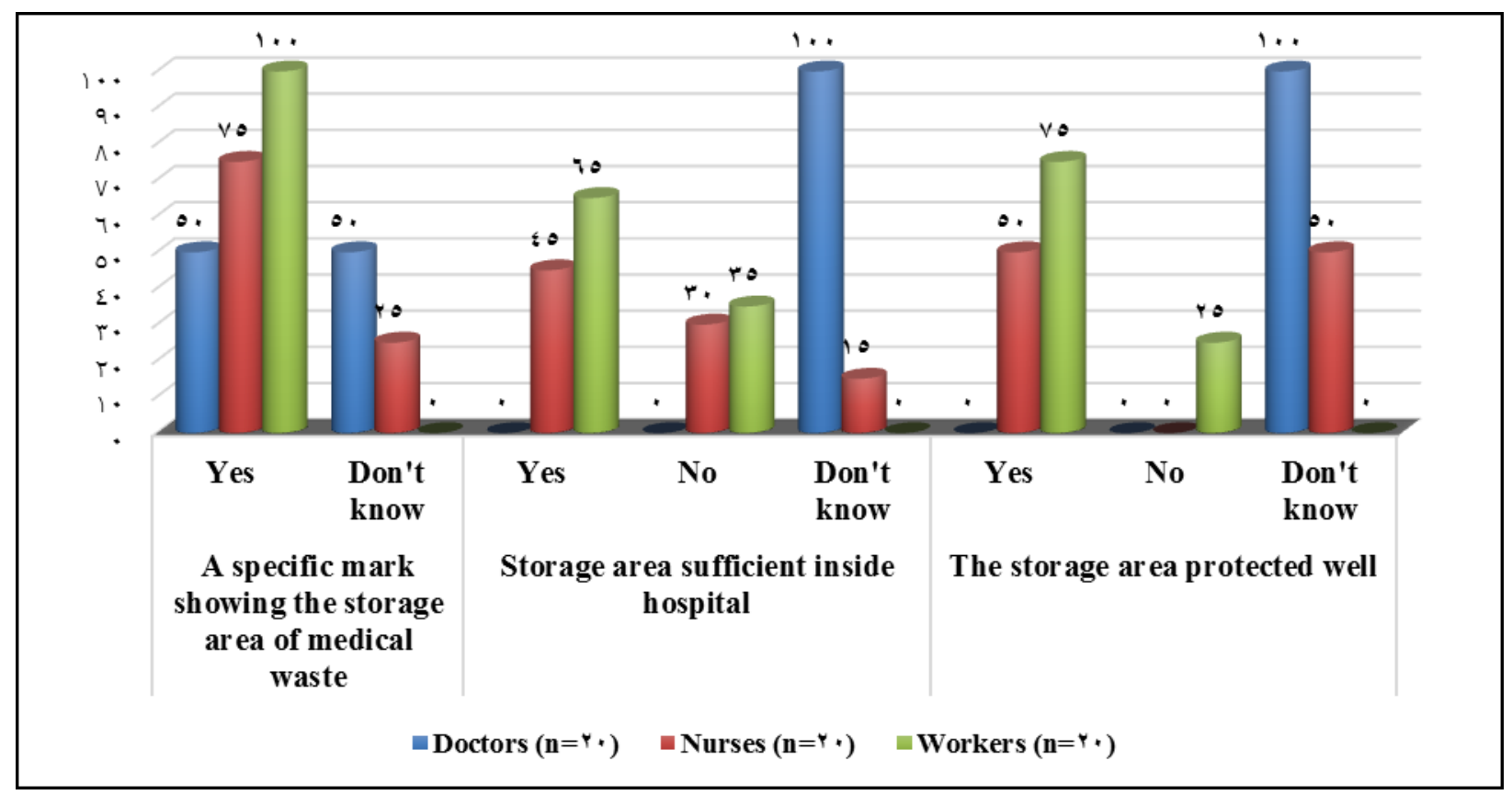


Figure (3): Percent distribution of the study sample information regarding a clean the means of transporting the waste, the surface of the transportation smooth and waste transferring means permeable to liquids $(n=60)$

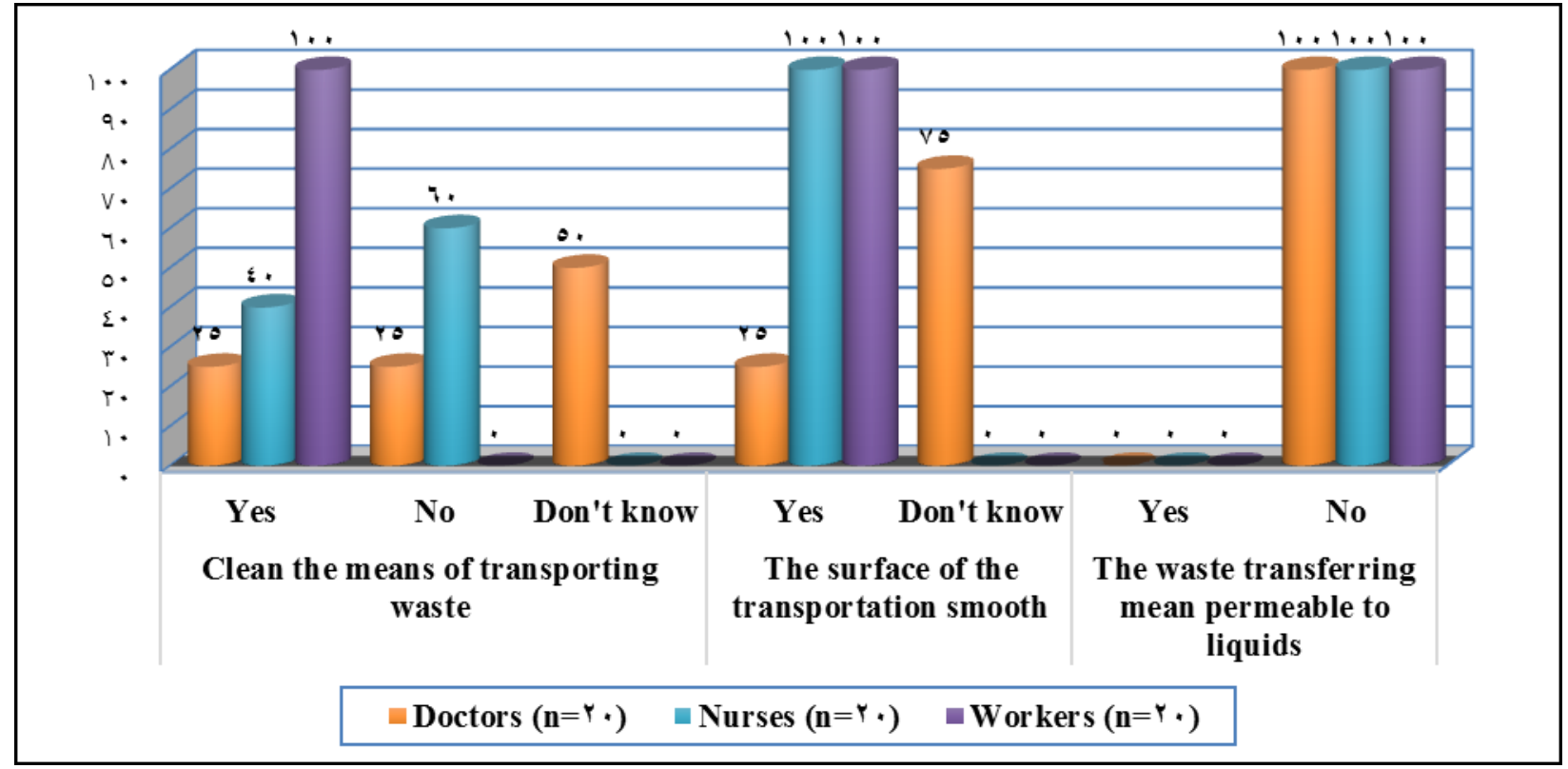

Figure (4): Percent distribution of the study sample related to the information regarding medical waste sharp box $(n=60)$

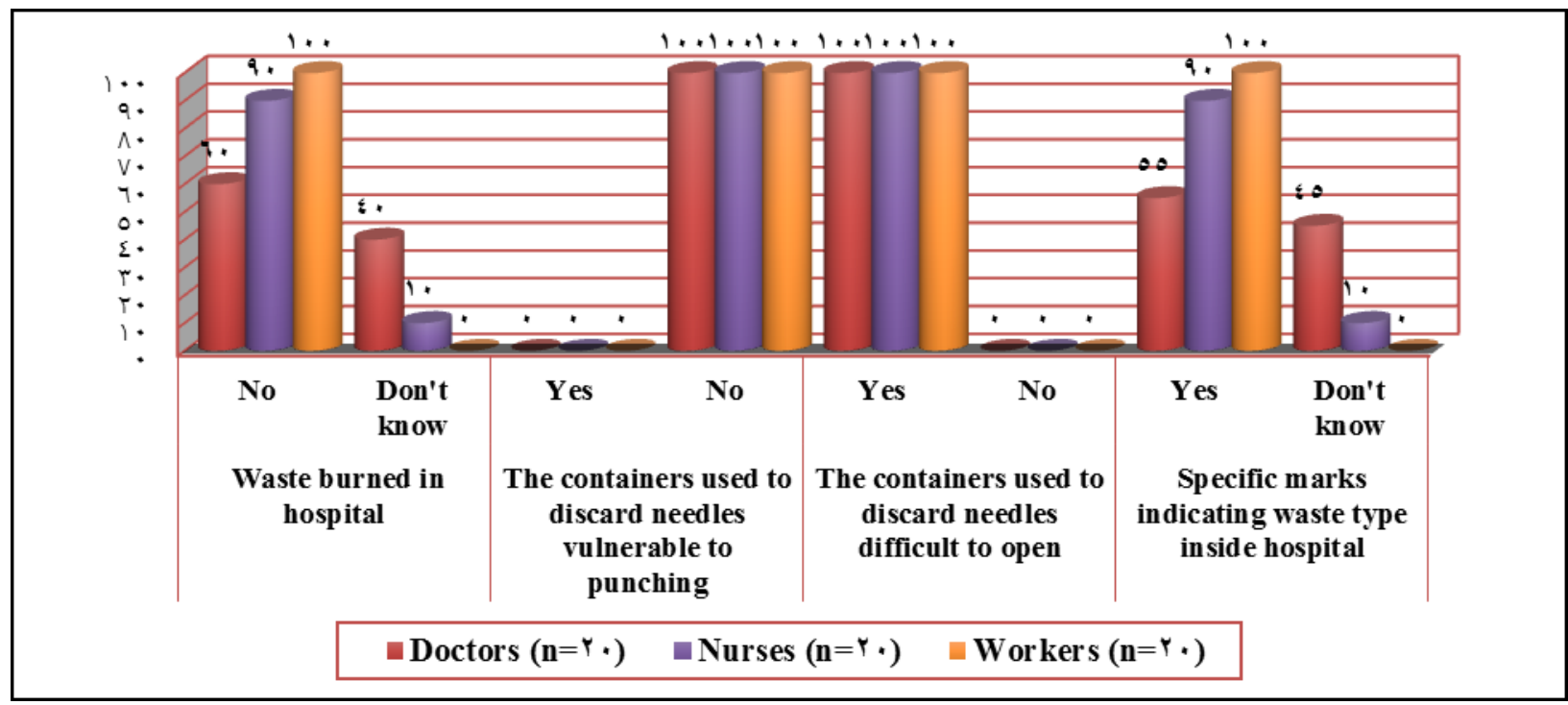

\section{Discussion}

Healthcare waste management has become a critical issue and has taken a central place in national health policies of many countries (Bdour, 2007) Poor management of health care waste potentially exposes health care workers, waste handlers, clients, and the community at large to infection, toxic effects and injuries, and risks polluting the environment. It is essential that all medical waste materials are segregated at the point of generation, appropriately treated and disposed of safely 
(WHO, 2011). Proper handling and disposal of bio-medical waste are very essential. Unfortunately, laxity and lack of adequate knowledge and practice on bio-medical waste disposal lead to staid health and environment apprehension (Tsakona et al., 2013).

It was evident from the present study's results that, almost of nurses $(95.0 \%)$ were female and $60 \%$ of nurses had a diploma. The results of the current study were supported by Alaa (2018) as the largest share in the study was for females, where they formed more than two-thirds of the study sample. Regarding the academic achievement of the nurses, nearly two-fifths of the study sample were graduates of technical diploma program in nursing. This is due to the reluctance of male sex to practice nursing and to go to other specialties because of poor job satisfaction in the nursing profession.

The present study revealed that $40.0 \%$ of the doctors, $45.0 \%$ of the nurses and less than two thirds $(60.0 \%)$ of workers had more than five years working in the hospital. The results of the current study go in line with studies done by (Sz Quazi, et al., 2012) among private medical practitioners in a slum area of Mumbai that revealed that less than half of the sample had $\leq 10$ years of experience. Regarding training to deal with medical waste by type, there was found almost the doctors $(90.0 \%)$, half of the nurses $(50.0 \%)$ and three-quarters of the workers $(75.0 \%)$ no received any training. The results of the current study were supported by Sahar et al., (2016) who reported that there is a lack of educational training programs for health care workers pre- and post-employment regarding medical waste management and related health hazards. The educational training program was given only to the infection control team as reported by health care workers. Moreover, the waste collector worker's experience was less than 6 months due to the turn of the housekeepers who deal with the collection and transportation of waste without a job description.

It was evident from the present study's results that all of the study samples answered there was color coding for waste separated in the hospital. These results were supported by the Ministry of Health (2012) recommendations, which reported that using the color-coding system is important to enhance segregation practices. Careful segregation of waste into different categories helps to minimize the quantities of hazardous waste.

It was evident from the present study's results that all of the nurses $(100.0 \%)$ indicated that cleaning workers and medical staff who carry on the process of separation and $50 \%$ of workers indicated cleaning workers who carry on the process of separation. This was supported by (Nagaraju, et al., 2013) who stated that segregation is the responsibility of the person who introduces health care to the patient, it must be done at point where was generated and immediately after giving the care because practical segregation at the source is the main factor that enables health 
care facility to save money on cost of waste disposal. Always keep separate containers inconvenient places wherever both municipal and hazardous are generated.

It was obvious that all of the nurses and workers indicated that the wastes containers or bags are defined and distinguished. This result was in agreement with Amira et al., (2017) who found that clear identification of each type of waste by color code or system was available in all departments and units. This was in concordance with the study by Kumari et al. (2012), who reported appropriate segregation and labeling of healthcare waste storage receptacles at the studied hospital in China, and a bar-coded tracking system for healthcare waste is under construction.

Regarding the transfer of waste bags from place to another easily, $50.0 \%$ of the doctors and workers and three-quarters of the nurses (75.0\%) answered yes always... The item on the procedures implemented to prevent the leakage of fluid from the bags $30 \%$ of the doctors and the nurses and $50.0 \%$ of the workers answered no. This result was in agreement with Amira et al., (2017) who found that the collection of waste in Tanta University Hospitals was done regularly. The same was also observed in a study conducted by Bdour et al., (2007) in Jordan, which revealed that collection is done regularly by a private company at the beginning of each shift. Similar to the results of the present study other studies conducted in Bangladesh and India they found that there was a poor practice among health care waste Arshad (2011) and Moreira, (2013).

It was observed that half of the doctors (50.0\%) and all of the nurses and the workers $(100.0 \%)$ were answered the medical waste stored in a special place inside the hospital building temporarily. This also goes hand-in-hand with a study conducted by Soliman and Ahmed (2017) in Egypt revealed that some departments stored their healthcare waste inside the utility rooms such as surgical, medical, laboratory, and ICUs, whereas labor rooms, operating rooms, and dialysis units do not store healthcare waste in the department, but the waste is immediately transported to the general storage area of the hospital, which was located on the basement floor near to the exit door or near the incinerator. Despite this result, a study was done by Amira et al., (2017) who revealed that there was no storage area for the produced waste and the storage containers are located at the shoulder of the street outside the hospital building and the area is fully accessible to animals and people.

Waste Management is one of the key problems of modern society due to the everexpanding volume and complexity of discarded waste This creates a need for more research on current disposal methods and corporate awareness, and general education (Patway, et al., (2011). 


\section{Conclusion}

Based on the findings of the present study, it can be concluded that there was proper knowledge among all health care workers related to waste segregation regarding general, infectious and sharps waste. workers have knowledge related to color-coded bags and medical waste storage and transport despite not reading the written policies of waste management. Our findings also revealed a gap between current knowledge of hospital waste management among health-care workers and that demanded by hospital waste management implementation policies. All the storage waste rooms were inappropriate, the studied hospitals had records for delivered and received wastes but these records were incomplete.

\section{Recommendations}

\section{Based on the findings of the present study, the following recommendations were recommended:}

- Establish a medical waste system to implement the existing legislation.

- Establish a waste management team.

- Development of in-service training programs for health care workers.

- Written policies or clear procedures of waste management should be available at ambulatory clinics.

\section{References}

1- Alaa N, Sarkees. Assessment of nurses' knowledge about health care waste management in duhok city. Polytechnic Journal. 2018; 8(2): 35-43.

2- Amira K. El-Dawla Mokhtar El-Shinawey, Atalla A, Khalil M. Abbas, Samir Abd El-Mageed Atlam Assessment of hospital waste management in Tanta University Received 21 February 2017Accepted 16 July 2017Tanta Medical Journal, 2017; 45: 146-154

3- Arshad N, Nayyar S, Amin F, Mahmood K. Hospital waste disposal: a review article. Journal Pharm Sci Res 2011; 3: 1412-1419

4- Bdour A, Altrabsheh B, Hadadin N. \& Al-Shareif M. Assessment of medical wastes management practice: A case study of the northern part of Jordan, Waste management. 2007; 27(2): 746-759

5- Dawson B. D \& Trapp R. G: Reading the medical literature: Basic \& Clinical Biostatistics. Lange Medical Book/ McGraw - Hill. Medical Publication Division, New York. 3rd ed., Ch. 7-9, PP 161-218 and Ch. 13, PP 305-314, 2001

6- Egyptian Prime Minister (2019). Executive Decree No. 338/1995 and No. 1741/2005 concerning the Environmental Law.1994;4. Government Printing 
House, Cairo, and amended by executive regulation. ww.moee.gov.eg/.../ESIA_220kv_OHTL_Ras_GharibWind_BOO_April_2019 - MS.

7- El-Sayed S. H, Zakaria A. M, \&. Gheith N. A. Intervention Program for Nurses about Health Care Waste Management. Research Journal of Medicine and Medical Sciences. 2012; 7(1): 25-37.

8- Gurung N. S, Paudel K, \&Pun C. B: Needlestick injuries among health care workers in a tertiary care teaching hospital, Pokhara, Nepal, Journal of Gandaki Medical College - Nepal, Jan-Mar .2010; 3(1): 1989-1992.

9- International Committee of the Red Cross (ICRC). Medical waste management. Geneva, Switzerland, www. icrc.org. 72 International. Journal. Environment. 2011; 3(1): 63-72.

10-Kumari R, Srivastava K, Wakhlu A, \&Sighn A. Establishing a biomedical waste management system in the Medical University of India: a successful practical approach. Clin Epidemiol Global Health 2012.

11-Labib O, Hussein A, Zakaria A, \& Mohamed M. Evaluation of Medical Waste Incinerators in Alexandria. The Journal of the Egyptian Public Health Association (JEPHAss.). 2005; 80(1): 3-4.

12-Manyele S. V. \& Lyasenga T. Factors affecting medical waste management in low-level health facilities in Tanzania. African Journal of Environmental Science and Technology. 2010; 4(5): 304-318.

13-Ministry of Health, the National Health Care Waste Management Plan, 20082012, KENYA.

14-Moreira AM. \& Gunther WM. Assessment of medical waste management and a primary health care center in Sao Paulo, Brazil. J Waste Management 2013; 33: $162-167$

15-Nagaraju B, Padmavathi, G, \& Puranik, D. A study to assess the knowledge and practice on bio-medical waste management among the health care providers working in PHCs of Bagepalli Taluk with the view to prepare informational booklet". International Journal of Medical Biomed and Research. 2013; 2(1): 28-35.

16-Pasupathi p, Sindhu B, Ponnusha \& Ambika A. Biomedical waste management for the health care industry. International Journal of Biol Med Research. 2011; 2(1): 472-486. 
17-Patway M, O'Hare T, \& Sarker M. Assessment of occupational and environmental safety associated with medical waste disposed of in developing countries: A qualitative approach. Safety science. 2011; 49(8-9): 1200-1207

18-Sahar M S, Magda A M. Medical Waste Management Situation at Alexandria Ambulatory Clinics IOSR Journal of Nursing and Health Science (IOSRJNHS) e-ISSN: 2320-1959.p- ISSN: 2320-1940 Volume 5, Issue 5 Ver. V (Sep. - Oct. 2016), PP 01-09.

19-Soliman SM, \& Ahmed AI. Overview of biomedical waste management in selected Governorates in Egypt: a pilot study. Waste management. 2017; 27(4): 1920-1923.

20-Sz Quazia A, Abhay G, Kanchan M, Shanbhag S, Pandit D. Universal precaution and safe waste disposal among private medical practitioners in aslum area of Mumbai. Indian Journal Of Occupational Health. Apr-Jun.2012; 21(2): 89- 94

21-Tsakona M, Anagnostopoulou E, Gidarakas E., (2013): Hospital waste management \& toxicity evaluation, Greece. Department of environmental engineers, Technical University of Crete. 6th. AvailablefromURL http://www.ncbi.nlm.nih.gov/pubmed. Results Panel.

22-WHO, (2011): Health care waste management Available at http://www.who.int/mediacentrefactsheets/Fs281/en/index.html? Retrieved at 3. Oct, 2012, 8:45pm. 